\title{
BAGASSE COMBUSTION FOR MOLASSES PROCESSING UNIT A CASE STUDY
}

\section{T. H. Ghanem ${ }^{1}$ ， M. M. Badr' ${ }^{2}$ M. M. Geasa ${ }^{3}$ and A.H.Elhelally ${ }^{4}$}

\section{ABSTRACT}

The main objective of the present work is to study direct combustion system used to heat a molasses processing units from the following points: environmental nature of traditional raw bagasse as a solid fuel. A case study on three different private processing factories in El Minia Governorate upper Egypt (El Roda and Dear Mawas village) in Malawy City, CO emmitted from the first, second and third factories were 4.5, 8.9 and 24 times that of the acceptable range stated by the Egyptian environmental rules (2016). Some bagasse producers used raw bagasse of moisture content ranged between 12 to $35 \%$ wet basis. Higher moisture contents of bagasse fuel affect on the combustion efficiency in molasse processing units.

\section{INTRODUCTION}

ugarcane bagasse is one of fibrous residues after extraction of juice from cane stem which can used as a source of roughages for ruminants. Utilization of sugarcane bagasse as fuel is limited due to their bulkiness that hinders their transport to areas of consumption. FAO (2011).

Pandey, et al. (2000) and Manikandan, \& Moganraj (2014) reported that the sugarcane bagasse consists of approximately $50 \%$ of cellulose, $25 \%$ of hemicellulose is combustibles and $25 \%$ of lignin is combustible Monjeghtapeh and Kafilzadeh (2008) reported that the sugar cane bagasse is a residue widely generated in high proportions in agroindustry. It is bulky and quite non uniform in particle size. The sugar cane residue bagasse is a material consists of two distinct cellular constituents: thick walled relatively long, fibrous fraction derived from the rind, fibro vascular bundles dispersed throughout the interior of the stalk, and a pith fraction derived from the thin walled cells of the ground tissue.

\footnotetext{
${ }_{1}^{1}$ Prof., Agric. Eng. and Deputy Dean of Fac, of Agric. Eng., Al-Azhar Univ, Cairo.

${ }^{2}$ Lecturer of Agric. Eng., Fac of Agric. Eng., Al-Azhar Univ, Cairo.

${ }^{3}$ Lecturer of Agric. Eng., Fac of Agric. Eng., Al-Azhar Univ, Assiut.

${ }^{4}$ Demonstrator of Agric. Eng., Fac of Agric. Eng., Al-Azhar Univ, Assiut.
} 
Aigbodion, et al. (2010) reported that the utilized various industrial and agricultural waste products in the industry has been the focus of research for economic, environmental, and technical methods. Sugarcane bagasse is a fibrous waste-product of the sugarcane industry. This waste-product is already causing serious environmental pollution. Anthony, et al. (2012) added that the sugarcane bagasse is a residue that results from the crushing of sugarcane in the sugar industry. Among the various agricultural crop residues, sugarcane bagasse is the most abundant lignocellulose material in tropical countries such as South Africa. They also reported that the sugarcane bagasse storage in uncovered stock piles has the potential to result in adverse impacts on the environment and surrounding communities through hazards associated with nuisance dust. Groundwater sewage, spontaneous combustion and generation of contaminated leachates. Managing these hazards will assist in improved health and safety outcomes for factory staff and reduced potential environmental impacts on surrounding communities. FAO (2012) reported that the sugar cane is one of the important commercial crops grown in tropical regions. Bagasse is a fibrous residue after extraction of juice from sugar cane is an important co-product, generated in large quantities. Currently, a major part of bagasse is used as a source of fuel in the sugar production factories. It is also used as raw material in board and paper manufacture. Hamed et.al. (2015) reported that bagasse is a fibrous residues remaining after squeezing. Juicing of sugarcane which is about 22 to $30 \%$ of sugarcane weight. It is usually used as a solid biomass fuel. They also concluded that every about 4-5ton bagasse equal to about one ton of coal in calorific value. According to the annual report of Egypt sugar crops council (2016) sugarcane cropping pattern, number of molasses factories, cultivated areas, juiced sugarcane in tons, average productivity and amount of molasses produced in tons is depicted in Table (1). Nakhla and El Haggar (2012) mated that the low efficiency (60\%) of bagasse is due to its low energy content per unit volume. They added that uncontrolled burning, approximately $30 \%$ of bagasse does not burn, and bulk is disposed in dumpsites instead of being utilized. 
Table (1): Statistics annual report of Egypt sugar crops council 2016

\begin{tabular}{cccccc}
\hline Governorate & $\begin{array}{c}\text { NO. of } \\
\text { sugarcane } \\
\text { traditional } \\
\text { factories }\end{array}$ & $\begin{array}{c}\text { Cultivated } \\
\text { area in } \\
\text { Fadans }\end{array}$ & $\begin{array}{c}\text { Juiced } \\
\text { sugarcane } \\
\text { in tons }\end{array}$ & $\begin{array}{c}\text { Avg. } \\
\text { productivity } \\
\text { Ton/ Fadan }\end{array}$ & $\begin{array}{c}\text { Amounts } \\
\text { of } \\
\text { molasses } \\
\text { in tons }\end{array}$ \\
\hline El Menia & 104 & 6123 & 288348 & 47.1 & 33472 \\
\hline Qena & 173 & 5273 & 221080 & 41.9 & 19278 \\
\hline Total & 277 & 11396 & 509428 & 44.7 & 52750 \\
\hline
\end{tabular}

Janghathaikul and Gheewala (2006) reported that bagasse as energy source is friendly to global environment but affects local environment adversely as shown in table (2) and table(3). Tables (2) and (3) summarize the interpretation and environmental problems of the bagasse power plant. The problem of high TSP emission can be addressed by installing dust control equipment such as ESP or bag filter in addition to the existing multi-cyclone. $\mathrm{CO}$ emissions might be reduced by pre-drying the bagasse using waste heat from the flue gas and also by improving the operation control. Thus, bagasse could become a sustainable and benign energy source.

Table (2): Interpretation summary of bagasse power plant

\begin{tabular}{|c|c|c|}
\hline Category & $\begin{array}{c}\text { Effect on } \\
\text { environment }\end{array}$ & Reasons \\
\hline $\begin{array}{l}\text { Global warming } \\
\qquad(\mathrm{GW})\end{array}$ & Positive & $\begin{array}{c}\mathrm{CO}_{2} \text { emission is a part of the global carbon } \\
\text { cycle. }\end{array}$ \\
\hline $\begin{array}{l}\text { Photochemical } \\
\text { ozone Formation } \\
(\mathrm{PO}) \\
\end{array}$ & Negative & $\begin{array}{c}\text { High CO emission due to high moisture } \\
\text { content and lack of adequate operation } \\
\text { control. }\end{array}$ \\
\hline Acidification (AC) & Positive & Low $\mathrm{SO}_{2}$ and $\mathrm{NO}_{2}$ emissions. \\
\hline $\begin{array}{l}\text { Nutrient enrichment } \\
\text { (NE) }\end{array}$ & Positive & $\begin{array}{l}\text { Low } \mathrm{N} \text { as } \mathrm{NO}_{2} \text { emission to air and wastewater } \\
\text { and ash do not have any } \mathrm{N} \text { and } \mathrm{P} \text {. }\end{array}$ \\
\hline $\begin{array}{l}\text { Solid waste to be } \\
\text { landfilled (SL) }\end{array}$ & Positive & $\begin{array}{l}\text { It is good for waste management in sugar } \\
\text { industry to utilize bagasse rather than } \\
\text { dumping to landfill. }\end{array}$ \\
\hline
\end{tabular}

* Janghathaikul and Gheewala (2006). 
Table (2): Problems from power generation using bagasse

* Janghathaikul and Gheewala (2006).

\begin{tabular}{ccc}
\hline Problems & $\begin{array}{c}\text { Effect to } \\
\text { environment }\end{array}$ & Reasons \\
\hline $\begin{array}{c}\text { High CO } \\
\text { emission }\end{array}$ & Negative & $\begin{array}{c}\text { Incomplete combustion because of the } \\
\text { varying moisture content of bagasse and } \\
\text { inadequate operation control. }\end{array}$ \\
\hline $\begin{array}{c}\text { High total } \\
\text { suspended } \\
\text { particulates } \\
\text { (TSP) } \\
\text { emission }\end{array}$ & Negative & $\begin{array}{c}\text { Turbulent movement of gases during } \\
\text { bagasse combustion and not sufficient } \\
\text { flue gas treatment. }\end{array}$ \\
\hline
\end{tabular}

Permchart and Kouprianov (2004) listed the properties of ultimate and proximate analysis of biomass fuel included bagasse in Table (4).

Table (3): Properties of biomass fuels used in the experimental tests Fuel Ultimate analysis (wt.\%, daf) Proximate analysis (wt.\%)

\begin{tabular}{cccccccc}
\cline { 2 - 7 } & $\mathbf{C}$ & $\mathbf{H}$ & $\mathbf{O}$ & $\mathbf{N}$ & $\mathbf{S}$ & $\mathbf{W}$ & $\mathbf{A}$ \\
\hline Sawdust & 45.43 & 6.71 & 47.65 & 0.19 & 0.02 & 15.9 & 0.61 \\
\hline Rice husk & 48.45 & 6.16 & 44.62 & 0.55 & 0.22 & 10.3 & 19.54 \\
\hline Bagasse $^{\mathrm{a}}$ & 42.00 & 6.58 & 51.00 & 0.26 & 0.16 & 14.4 & 1.84 \\
\hline
\end{tabular}

${ }^{\mathrm{a}}$ Pre-dried under room conditions from $\mathrm{W}=48.8 \%$ (as-delivered) to $\mathrm{W}=14.4 \%$.

$* \mathrm{~W}=$ moisture, $\mathrm{A}=$ ash, daf $=$ dry and ash-free basis

The anticipated advantages of using agricultural residues for energy production are reduction in air emissions, especially $\mathrm{CO} 2, \mathrm{NOx}$ and SOx. Their utilization also contributes to waste management, reduction in electricity purchase at the generating facility (e.g. rice or sugar mills) and even profit from selling surplus electricity to the grid. 
The problems are their low energy leading to increased transportation requirements if they are not utilized at the generation point, high moisture content leading to incomplete combustion and seasonal variability. Premachart and Kouprianov (2004) studied the effect of excess air on $\mathrm{CO} \& \mathrm{NO}$ emitted and tabulated the results in Table (5).

They concluded that when air increases $\mathrm{CO}$ emission decreased, while NO emission increased when using bagasse fuel.

Table (5): CO and NO emission as effected by excess air.

\begin{tabular}{cccc} 
fuel fired & $\begin{array}{c}\text { Excess air } \\
(\text { vol\% })\end{array}$ & $\begin{array}{c}\text { CO emission } \\
(\text { vol\%) }\end{array}$ & $\begin{array}{c}\text { NO emission } \\
(\text { vol\%) }\end{array}$ \\
\hline \multirow{3}{*}{ Bagasse } & 17.3 & 1.529 & 91 \\
& 60.7 & 0.312 & 116 \\
& 101.1 & 0.101 & 131 \\
\hline
\end{tabular}

\section{MATERIAL AND METHODS}

\section{Materials:}

Row molasses is obtained by crushing, squeezing and sieving sugar cane. Juice is then clarified evaporated and concentrated by heating and then cooled to be a molasses. Solids remained after crushing and squeezing sugar cane was bagasse. In a molasses processing units solid raw bagasse is dried and usually used as a fuel for combustion process. Juice concentration process is performed in molasses oven. Fig. (1) shows a flow chart of molasses production. Molasses oven is a longitudinal oven of length, width and height of about $13 \times 5 \times 4$ m built of bricks $40 \mathrm{~cm}$ thickness of thermal conductivity $0.2 \mathrm{~W} / \mathrm{m} . \mathrm{K}$ Bergman and Incropera, (2011). has one or two production lines, each line has three or four pans for molasses concentration process, as shown in Fig. (2).

The chimney emitted gases were measured by portable emission analyzer used for measuring $\mathrm{O}_{2}, \mathrm{CO}, \mathrm{NO}_{\mathrm{X}}, \mathrm{SO}_{2}$, and ash, ambient temperatures, pressure, from the data obtained $\mathrm{CO}_{2}$, efficiency, dew point and excess air, can be calculated Fig. (3). 


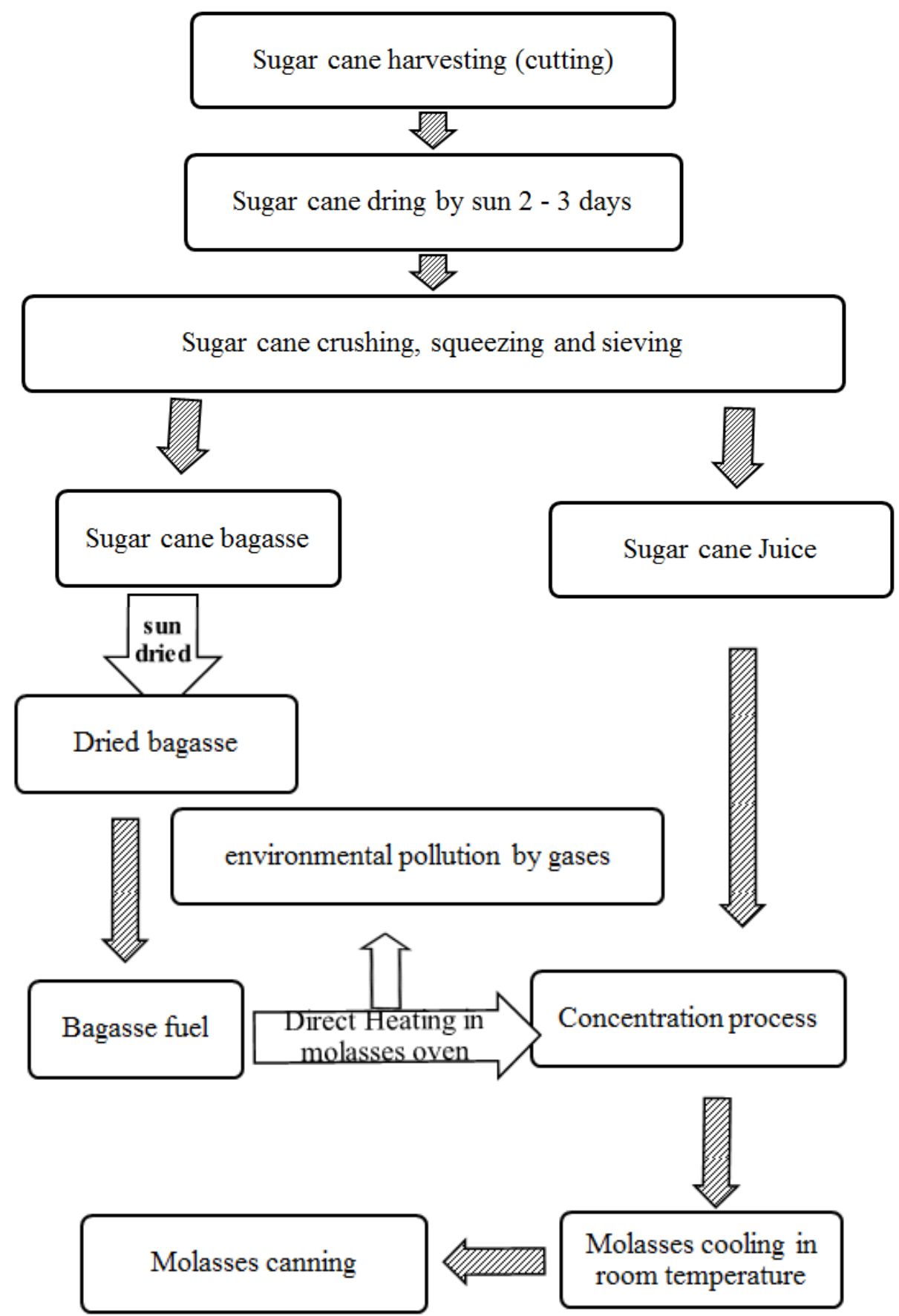

Fig. (1): Flow chart of classical methods for preparation of molasses production. 

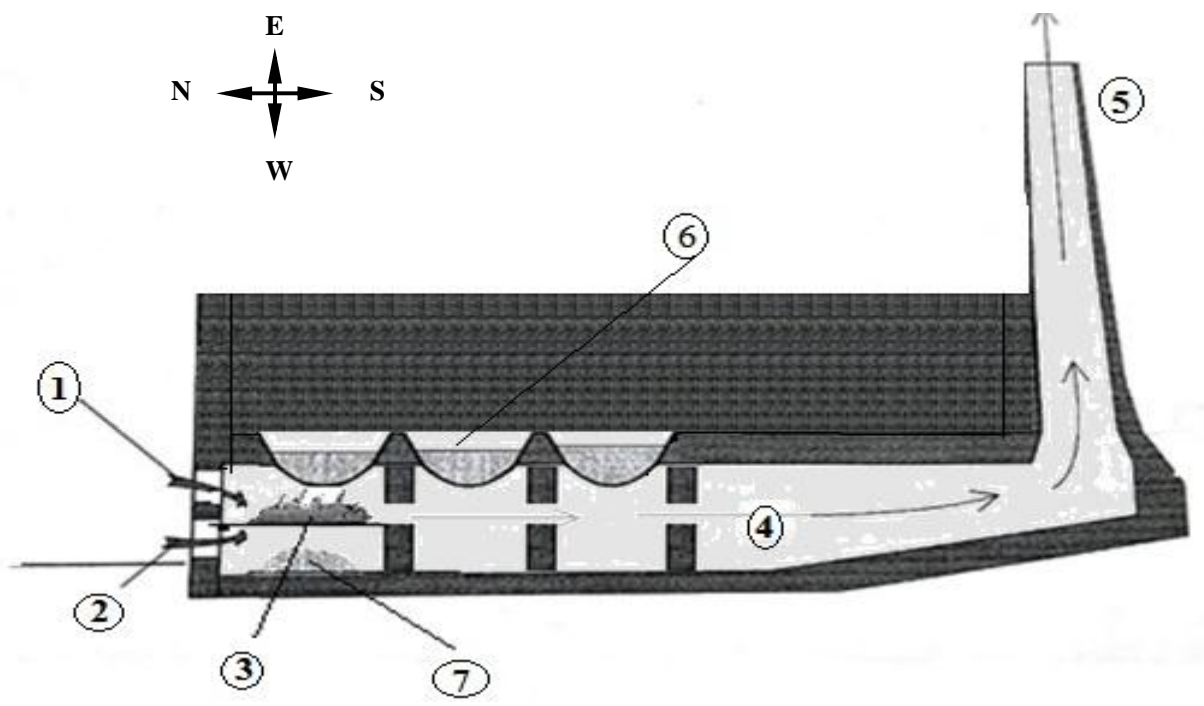

(1) Bagasse feed opening

(2) Air entry and ash exhausting

(3) Fire house

(4) Combustion gases out flam
(5) Chimney

(6) Pan made of copper

(7) Ash

Fig. (1): Elevation cross section of molasses factory

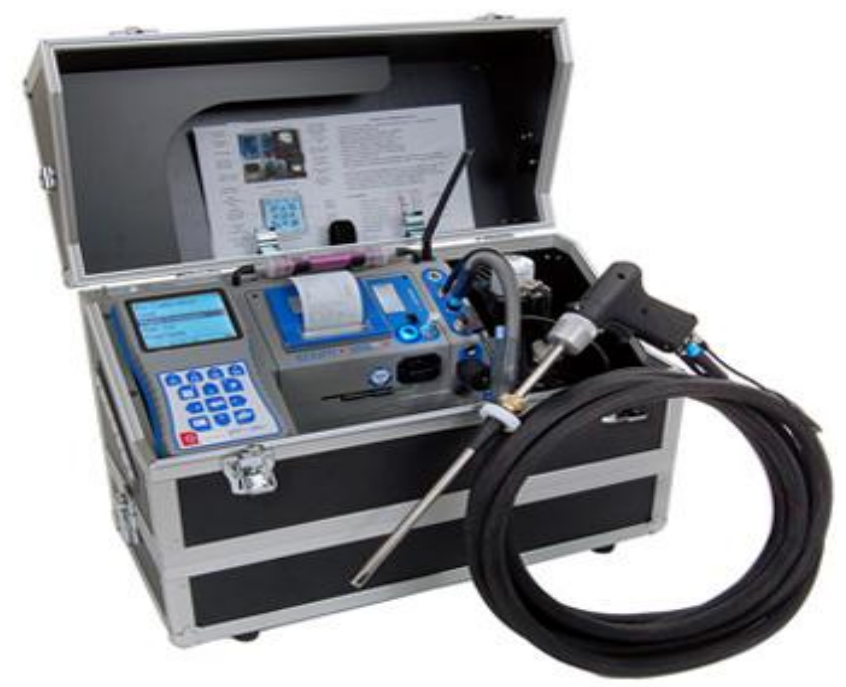

Fig. (3): Gases emission measuring device (ECOM J2KN - made in Germany) 


\section{METHODS}

The present work was carried out at several private factories in El Roda and Dear Maws villages in Malawi City, El Mina Governorate. Private small producers complained of lower combustion efficiency of bagasse.

1- Study the effect of combusting solid bagasse fuel in conventional molasses processing units.

2- Effect of manipulated additives on combustion process used at the private molasses processing factories.

3- Moisture contents required for complete combustion in molasses units and study the effect of combustion on environmental.

4- Is there enough air to complete the combustion process?

\section{RESULTS AND DISCUSSION}

In the present study environmental data were measured on different private bagasse processing factories in the sugar cane cultivation belt, El Roda and Dear Maws viltage in Malawi City, El Minia Governorate. Results showed that some molasses producers used raw bagasse of moisture content ranged between 12 to $35 \%$ wet basis. Table (6) shown some physical characteristics of dried bagasse.

Table (6): Physical characteristics of sun dried bagasse physical characteristics of bagasse

\begin{tabular}{ccc}
\hline & Bagasse & Dry bagasse \\
\hline Particle size & Between $10-170 \mathrm{~cm}$ & Between $10-50 \mathrm{~cm}$ \\
Bulk density & $120-145 \mathrm{~kg} / \mathrm{m}^{3}$ & $70-100 \mathrm{~kg} / \mathrm{m}^{3}$ \\
Moisture content & $50-59.5 \%$ & $12-35 \%$ \\
\hline
\end{tabular}

High moisture contents of bagasse fuel affect on the combustion efficiency in molasse processing units. Some factories use automotive rubber tires, and others supplemented it with another fuel as fuel oil to enhance the burning efficiency for the continuity of flame firing which in turn reflected on the existence of huge amounts of $\mathrm{SO}_{2}$ as presented in Figs. (4), (5) and (6). Fig. (7) shows a factory use bagasse only in combustion process. Table (7) summarized measurements of $\mathrm{CO}, \mathrm{NO}_{\mathrm{x}}$ and $\mathrm{SO}_{2}$ emitted during molasses processing in the three factories. It is clear that $\mathrm{CO}$ for all factories and $\mathrm{SO}_{2}$ for that factory use automotive tiers in combustion process were with the unacceptable ranges. 
The CO emmitted from the first, second and third factories were 4.5, 8.9 and 24 times that of the acceptable range stated by the Egyptian environmental rules. It is also clear that the first and second factories in the case study has zero $\mathrm{SO}_{2}$ emission compared in to $2689 \mathrm{mg} / \mathrm{m}^{3} \mathrm{SO}_{2}$ of the third factory used automotive tiers. The portable emission analyzer were depicted in Fig. (8).

Table (7): Gases emitted from combustion of bagasse.

\begin{tabular}{|c|c|c|c|c|c|}
\hline \multirow[b]{3}{*}{$\begin{array}{l}\text { Ultimate } \\
\text { analyses }\end{array}$} & \multicolumn{3}{|c|}{ Factories } & \multirow{2}{*}{$\begin{array}{c}\text { Acceptable } \\
\text { ranges }\end{array}$} & \multirow[b]{3}{*}{ Notes } \\
\hline & (a) & (b) & (c) & & \\
\hline & $\begin{array}{c}\text { Bagasse } \\
\text { M.C = } \\
12 \%\end{array}$ & $\begin{array}{c}\text { Bagasse } \\
\text { M.C = } \\
35 \%\end{array}$ & $\begin{array}{c}\text { Bagasse } \\
\text { M.C }=28 \% \\
\& \\
\text { automotive } \\
\text { rubber tires }\end{array}$ & $\begin{array}{l}\text { according to } \\
\text { Egyptian } \\
\text { environmental } \\
\text { rules }\end{array}$ & \\
\hline $\mathrm{Co}, \mathrm{mg} / \mathrm{m}^{3}$. & 1126 & 2246 & 6000 & 250 & unacceptable \\
\hline $\begin{array}{c}\mathrm{No}_{\mathrm{x}}, \\
\mathrm{mg} / \mathrm{m}^{3} .\end{array}$ & 419 & 307 & 414 & 500 & acceptable \\
\hline $\mathrm{So}_{2}, \mathrm{mg} / \mathrm{m}^{3}$. & -------- & ------ & 2689 & 100 & unacceptable \\
\hline
\end{tabular}

* ECOM J 2 K N Portable emission analyzer.

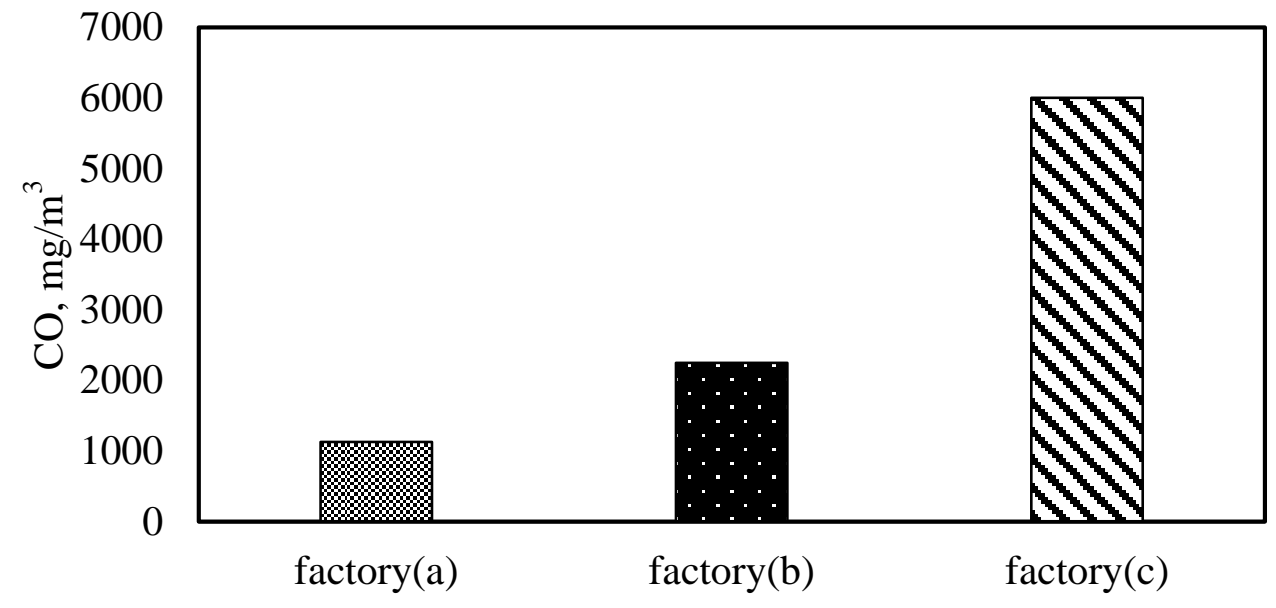

The three different factories

Fig. (4): $\mathrm{CO}$ emitted from the three molasses factories. 


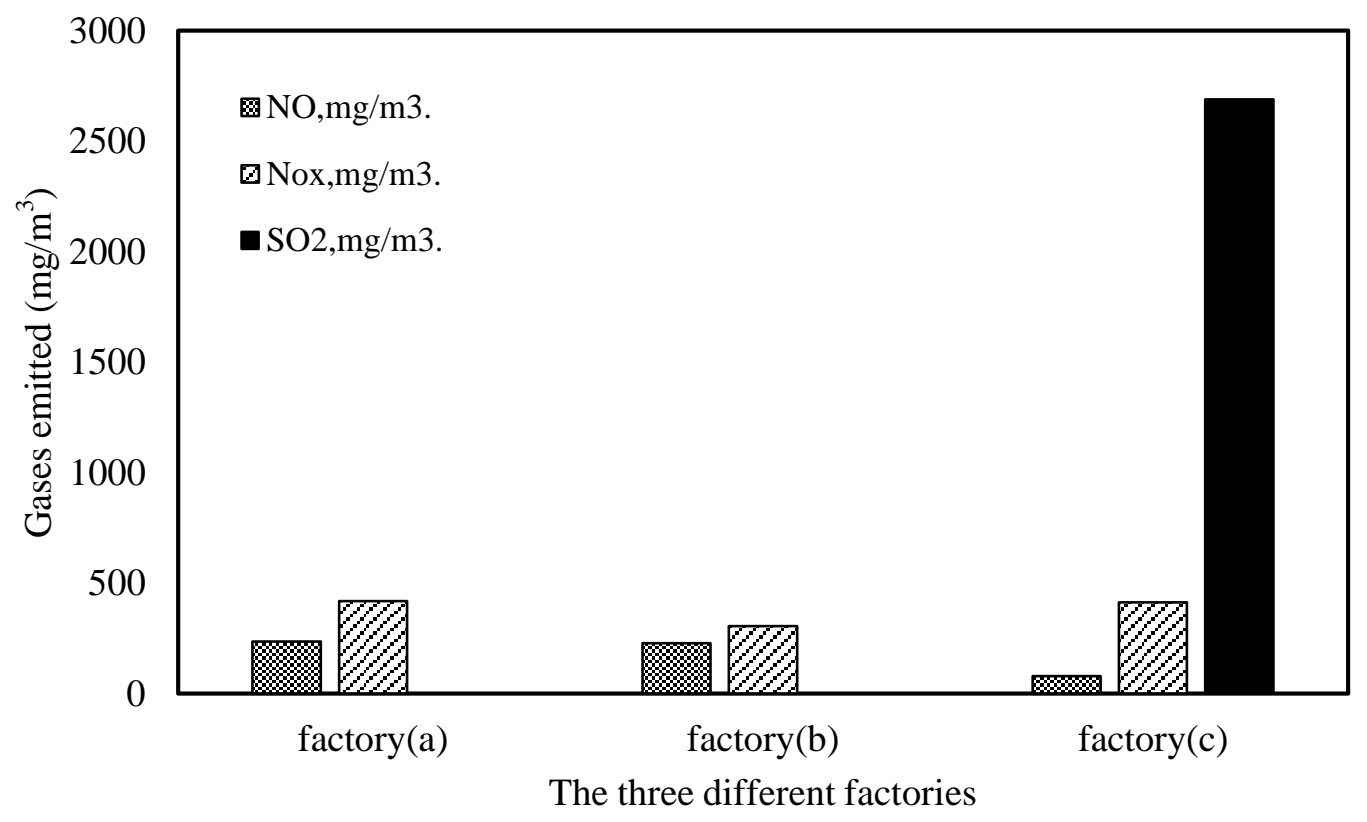

Fig. (5): Gases emitted from the three molasses factories.

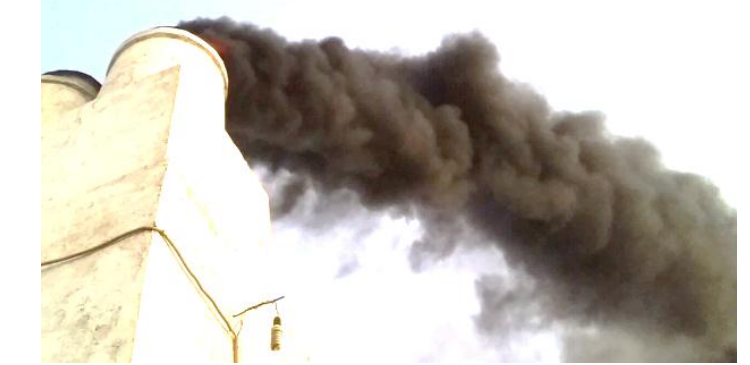

Fig. (6): Smoke intensity from the chimney of factory (c) use bagasse \& rubber.

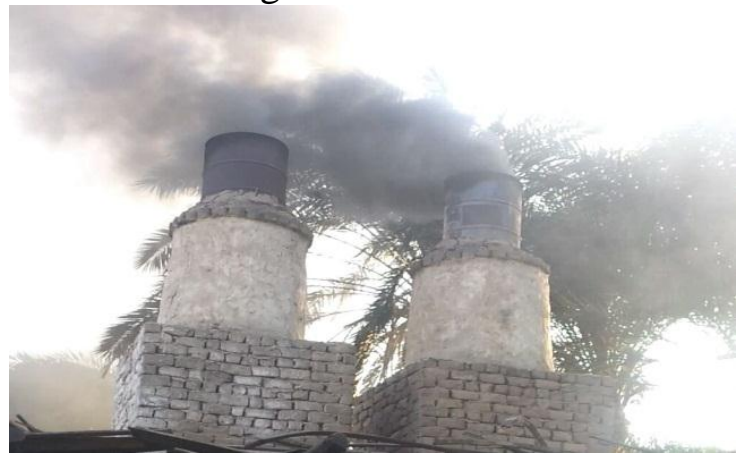

Fig. (7): Smoke intensity from the chimney of factory (b) use bagasse in combustion process. 
Fig. (8) Data sheets to case study by ECOM - J2KN

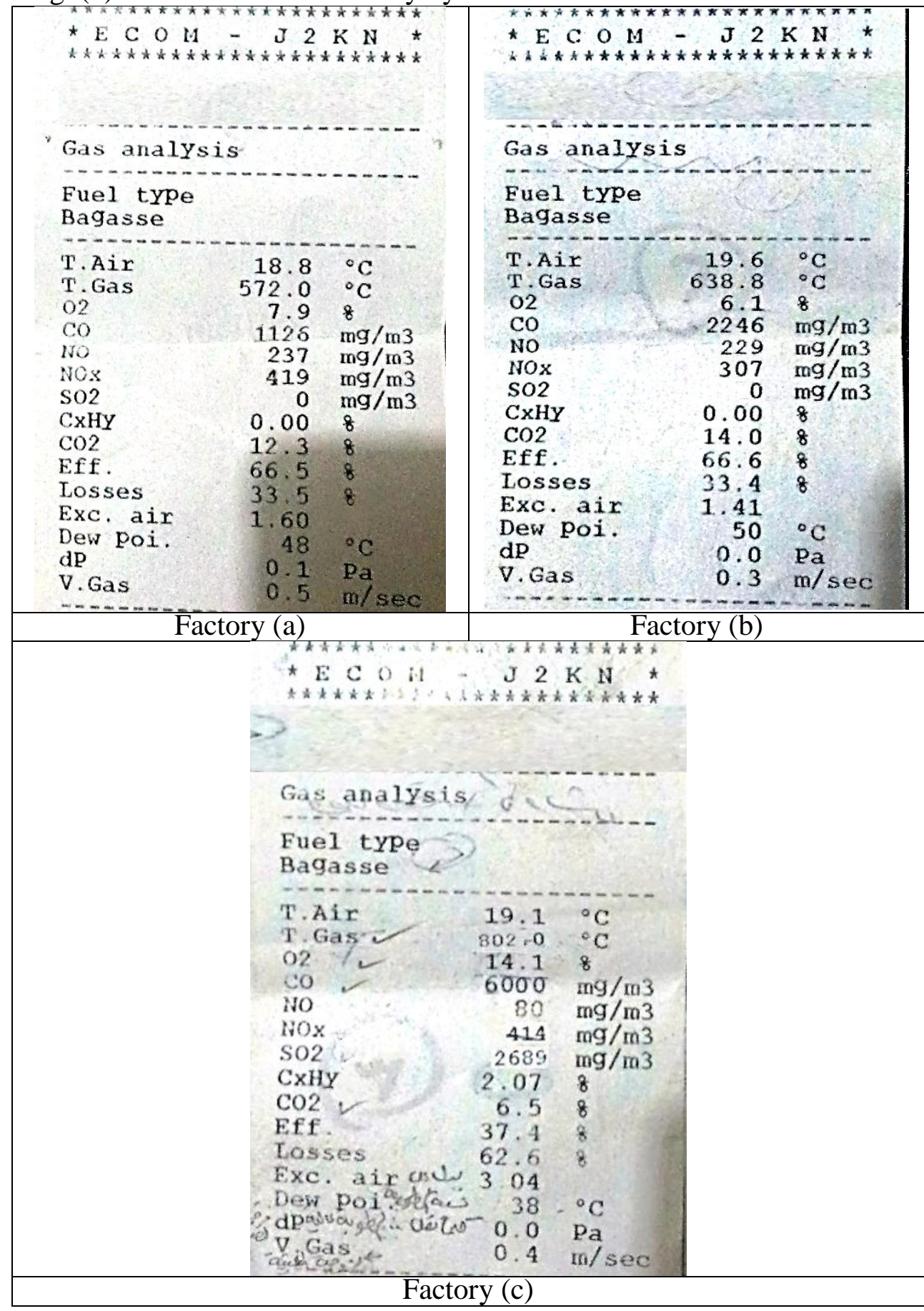




\section{CONCLUSION}

The main objective of the present work is to study the direct combustion using bagasse system to heat a molasses processing units and estimation of different gases liberated from bagasse incineration in molasses oven. The results showed that some molasses producers used raw bagasse of moisture content ranged between 12 to $35 \%$ wet basis. Some factories used automotive rubber tires, bagasse and others supplemented it with another fuel as fuel oil to enhance the burning efficiency as reported by Nakhla and El Haggar (2012) for the continuity of flame firing which in turn reflected on the existence of huge amounts of $\mathrm{SO}_{2}$ in $\mathrm{mg} / \mathrm{m}^{3}$. It is clear that $\mathrm{CO}$ for all factories and $\mathrm{SO}_{2}$ from third factories which used automotive tiers in combustion process were with the unacceptable ranges. The $\mathrm{CO}$ emitted from the first, second and third factories were 4.5, 8.9 and 24 times that of the acceptable range stated by the Egyptian environmental rules. It is also clear that the first and second factories has zero $\mathrm{SO}_{2}$ emission compared to $2689 \mathrm{mg} / \mathrm{m}^{3} \mathrm{SO}_{2}$ of the third factory used automotive tiers or their $\mathrm{SO}_{2}$ emission is 26.89 times that determined by the Egyptian environmental rules.

\section{Recommendations:}

1- Using bagasse as a fuel for: -

a- Decreasing production costs of molasses.

b- Prevent of emittion of toxic gases to environment such as $\mathrm{SO}_{2}$ emittion in rubber combustion.

c- Decreasing fibrous residues of bagasse amount resulting from sugar cane juice which prevents insects and putrefaction to protect human bean from infectious diseases.

2- Decreasing of bagasse moisture content before its combustion enhance the combustion process.

\section{REFERENCES}

Aigbodion, V. S.; S. B. Hassan; T. Pause; and G. B. Nyior, (2010). Potential Utilization of Solid Waste (Bagasse Ash). Printed in the USA. All rights reserved Vol. 9, No.1, (20): 67-77.

Annual report of Egypt sugar crops council(2016). Ministry of Agriculture and Land Reclamation. 
Anthony; Rainey; J. Thomas; O. Hara; M. Ian; Mann; Bakir; Hakan; and P. Floren, (2012). Effect of pelleting on the safety and environmental aspects of bagasse stockpiling. Process Safety and Environ. Protection. http://dx.doi.org/10.1016/j.ps.

Bergman, T. L., \& Incropera, F. P. (2011). Fundamentals of heat and mass transfer. John Wiley \& Sons.

FAO, (2011). Animal Production and Health Paper, (72):319 Available at: http://www.fao.org/ag/AGa/AGAP/FRG/ AHPP72/ah pp. 72 html. Accessed on 16 October 2011.

FAO, (2012). Scope for utilizing sugar cane bagasse as livestock feed an Asian perspective. Aquaculture Research 16: 291-302.

Hamed R.G., Sharaf M.S and Mohamed A.M. (2015). Principals of Food Technology. Food Science and Technology Fac. of Agric. Cairo, Al Azhar Univ: 254 (In Arabic).

Janghathaikul, D., and Gheewala, S. H. (2006). Bagasse-A Sustainable Energy Resource From Sugar Mills. In The Joint International Conference on "Sustainable Energy And Environment (SEE) (pp. 1$3)$.

Manikandan, A. T.; and M. Moganraj, (2014). Consolidation and rebound characteristics of expansive soil by using lime and bagasse ash. eISSN: 2319-1163 | pISSN: 2321-7308.

Monjeghtapeh, S. S.; and F. Kafilzadeh, (2008). Microbial direct feed in small ruminant nutrition. P-004, in: Agric. and bio systems Eng. for a sustainable world. International Conference on Agric. Eng., Hersonissos, Crete, Greece, 23-25 June 2008.

Nakhla, D. A., \& El Haggar, S. (2012)._Environmentally balanced sugarcane industry in Egypt.

Pandey, A.; C. R. Soccol; P. Nigam; and V. T. Soccol, (2000). Biotechnological potential of agro-industrial residues. I: sugarcane bagasse. Bio Resource Technol., (74): 69-80. 
Permchart, W., \& Kouprianov, V. I. (2004). Emission performance and combustion efficiency of a conical fluidized-bed combustor firing various biomass fuels. Bioresource technology, 92(1), 83-91.

الملخص العربي

إحتراق مخلف القصب (الباجاس) كوقود لوحدة تصنيع المولاس - دراسة حالة

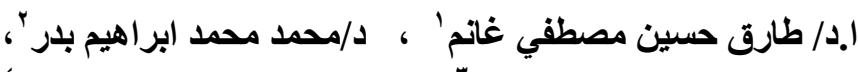

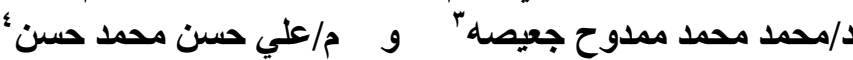

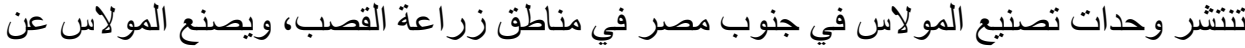
طريق تركيز عصير قصب السكر في قيز انات مفتوحة حيث ينم تسخين هذه القيز انات من أسفل

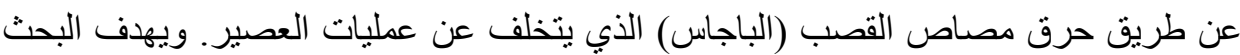

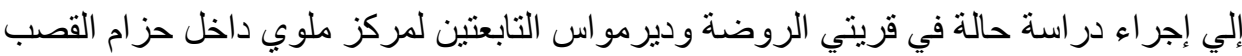

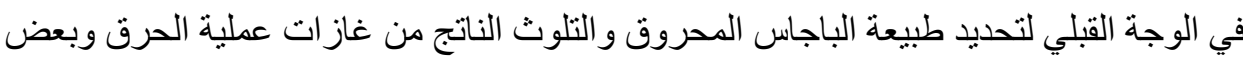
المؤشرات الهندسية لأفران تصنيع المولاس. وأوضحت التجارب أن أن نسبة تصاعد أول الكال اكسيد

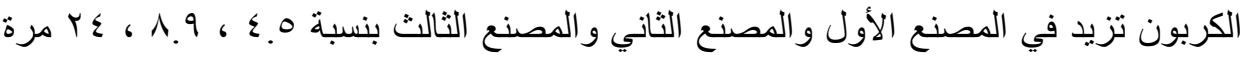

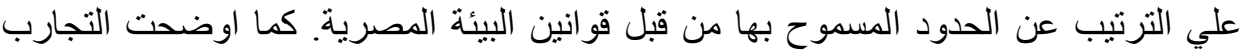

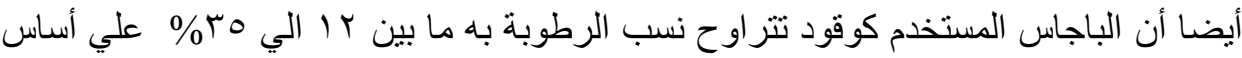

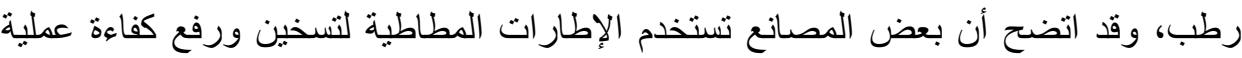

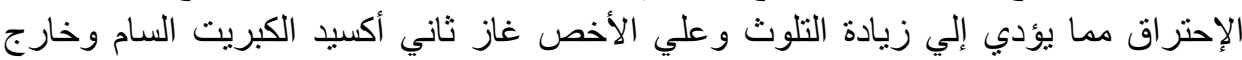

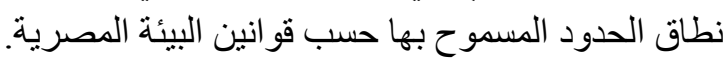

$$
\text { أتوصيات: }
$$

بـ تقليل المخلفات الناتجة عن عصر القصب وتلافي تأتثير ها علي البيئة حيث تعتبر

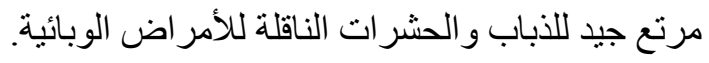

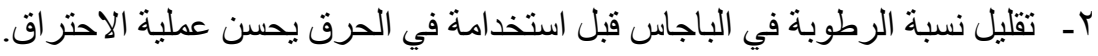

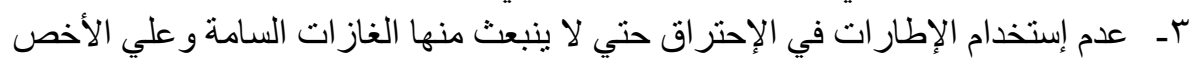

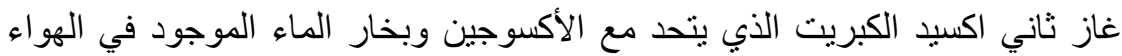

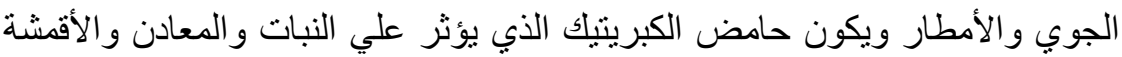

و المباني.

'أستاذ الهندسة الزراعية و وكيل كلية الهندسة الزراعية - جامعة الأزهر بالقاهرة.

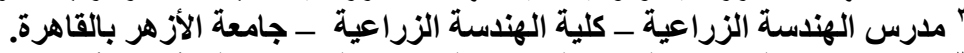

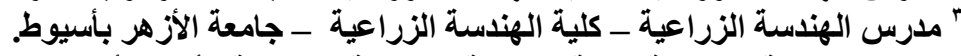

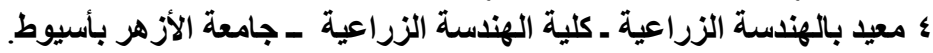

